DOI: https://doi.org/10.24127/ajpm.v9i3.2918

\title{
PENGEMBANGAN BAHAN AJAR BERBANTUAN MEDIA TUBOMATIKA UNTUK MENINGKATKAN KEMAMPUAN ABSTRAKSI MATEMATIS SISWA
}

\author{
Asep Ikin Sugandi ${ }^{1}$, Linda ${ }^{2}$, Martin Bernard ${ }^{3}$ \\ ${ }^{1,2,3}$ Pendidikan Matematika, IKIP Siliwangi, Cimahi, Indonesia \\ ${ }^{*}$ Corresponding author. Jl. Terusan Jend. Sudirman, 40521, Cimahi, Jawa Barat. \\ E-mail: $\quad$ asepikinsugandi@ikipsiliwangi.ac.id $^{1)}$ \\ ndal12996@gmail.com $^{2)}$ \\ pamartin23nrd@gmail.com ${ }^{3)}$
}

Received 08 July 2020; Received in revised form 13 September 2020; Accepted 26 September 2020

\begin{abstract}
Abstrak
Tujuan dari penelitian ini untuk mengembangkan bahan ajar matematika berbantuan media tubomatika terhadap kemampuan abstraksi matematis siswa kelas VII SMP. Kemampuan abstraksi matematis ialah kemampuan dasar yang harus dimiliki siswa SMP. Implementasi bahan ajar dengan menggunakan media tubomatika ini merupakan suatu cara untuk membantu siswa dalam memahami pembelajaran matematika terutama dalam materi segiempat dan segitiga. Agar bahan ajar berkualitas maka harus memenuhi kriteria valid, praktis, dan efektif. Penelitian ini menggunakan metode Research and Development ( $R$ and $D)$ melalui penggunaan model pengembangan Plomp yang terdiri atas fase investigasi awal, fase pengembangan (pembuatan prototipe), dan fase penilaian (evaluasi). Hasil yang diperoleh dari penelitian ini yaitu validitas bahan ajar dinyatakan sangat valid dengan hasil persentase $87 \%$ berdasarkan materi dan desain tubomatika bahan ajar, praktikalitas bahan ajar berdasarkan respon siswa dan guru sangat praktis dengan rata-rata persentase sebesar $82,20 \%$ dan efektivitas bahan ajar ini dapat dinyatakan efektif dalam meningkatkan kemampuan abstraksi siswa sebesar 71,27\%. Dengan demikian, disimpulkan bahwa bahan ajar berbantuan tubomatika sangat penting untuk diterapkan pada proses pembelajaran sehingga dapat berpengaruh terhadap peningkatan kemampuan abstraksi matematis siswa kelas VII SMP.
\end{abstract}

Kata kunci: Bahan ajar; kemampuan abstraksi; tubomatika.

\begin{abstract}
The purpose of this research is developing mathematics teaching materials that present in based tubomatika media to increase the ability of mathematical abstraction of students in grade VII junior high school. Mathematical abstraction ability is a basic ability that students must have. The application of teaching materials using tubomatika media is one way to assist students in understanding mathematics learning, especially on rectangle and triangular material. The teaching materials that provided for students must have three criterias are valid, practical, and effective. The type of this research is the Research and Development ( $R$ and $D$ ) and using the Plomp development model. This research consist of investigation phase, development or prototype phase, and assessment phase. The result of this development research are the validity of the teaching materials are valid with a percentage $87 \%$ on the theory aspect and the material design media tubomatika, practicality of teaching materials based on the response of teachers and students are practice with percentage $82,20 \%$, and the effectivity of teaching materials are effective based on communication skills of students with a percentage of 71,27\%. So, it can be concluded that the tubomatika based teaching material is very important to be applied in the learning process so that it can affect the improvement of mathematical abstraction abilities of grade VII students of junior high school.
\end{abstract}

Keywords: Abstraction ability ; teaching materials ; tubomatika.

This is an open access article under the Creative Commons Attribution 4.0 International License 
DOI: https://doi.org/10.24127/ajpm.v9i3.2918

\section{PENDAHULUAN}

Perkembangan adalah proses perubahan fungsional secara bertahap dan bersifat kualitatif yang dapat dialami oleh individu menuju tingkat kedewasaan, baik pada aspek fisik, afektif, maupun kognitif, (Basri, 2019). Hal ini terdapat pada kemampuan abstraksi yang dimiliki individu, dimana kemampuan abstraksi sangat penting bagi perkembangan logika dan keterampilan siswa dalam berpikir terutama siswa SMP. Menurut (Basri, 2019) pemikiran abstraktif meliputi; 1) mengambil kesimpulan khusus dari pengalaman yang umum, 2) mengambil kesimpulan umum dari pengalamanpengalaman yang khusus, dan 3) abstraksi tidak langsung dari objek melainkan siswa sudah mulai maju untuk memahami konsep proporsi dengan baik, bahkan sudah mampu menggunakan kombinasi dalam pemikirannya.

Dalam pembelajaran matematika kemampuan berpikir abstraksi sangat diperlukan siswa, terkait dengan kebutuhan siswa untuk menyelesaikan masalah yang dihadapinya di kehidupan sehari-hari, karena masalah yang dihadapi tidak hanya bersifat konkrit, sehingga dengan berpikir abstraksi dalam hal ini kemampuan menemukan cara-cara dalam menyelesaikan masalah tanpa hadirnya obyek permasalahan secara nyata. Namun pada kenyataannya, berpikir abstraksi matematis siswa SMP terhadap pembelajaran matematika cenderung masih rendah. Hal ini sesuai dengan penelitian yang telah dilakukan oleh Mandasari (2018) menyatakan bahwa siswa SMP masih merasa kesulitan dalam membuat kesimpulan dari hal-hal yang bersifat umum menuju hal-hal yang bersifat khusus dan tahap ini juga merupakan tahap berpikir yang tinggi, rumit dan kompleks, sehingga kemampuan abstraksi siswa SMP masih dikatakan rendah dalam memahami konsep pada pembelajaran matematika. Dalam melakukan kegiatan berpikir abstraksi siswa dituntut berpikir secara simbolik dan imajinatif untuk menyelesaikan masalah-masalah yang ada, terutama dalam matematika pada materi segiempat dan segitiga.

Dengan mempelajari materi segiempat dan segitiga tersebut, siswa dapat lebih mudah menyelesaikan permasalahaan di kehidupan sehari-hari yang berkaitan dengan konsep tersebut, seperti mengukur dan menghitung keliling dan luas tanah. Materi segiempat dan segitiga juga sangat penting untuk dipelajari dan harus dikuasai betul oleh siswa SMP kelas VII, karena menjadi materi prasyarat saat siswa duduk di kelas VIII berikutnya dalam mempelajari bangun ruang sisi datar. Namun, berdasarkan temuan di lapangan bahwa; 1) siswa belum memahami keterkaitan antar bangun datar segiempat dan segitiga, 2) siswa masih keliru dalam mengidentifikasi jenis-jenis segiempat dan segitiga, dan 3) siswa belum mampu untuk menemukan keliling dan luas segiempat dan segitiga secara mandiri. Sejalan dengan penelitian yang dilakukan oleh Dewi (2017) menyatakan bahwa siswa mengalami kesulitan dalam membedakan macammacam segitiga dan segiempat, bahkan masih keliru menyelesaikan soal cerita dalam materi segiempat dan segitiga.

Pembelajaran yang berorientasi pada masalah dunia nyata dan dapat dimengerti siswa, memungkinkan siswa akan lebih mudah ketika membangun pengetahuannya sendiri. Menurut Sugandi (2013) kemandirian belajar merupakan aspek yang sangat penting dalam pembelajaran matematika. 
Dengan menerapkan belajar secara mandiri, kemampuan berpikir siswa akan semakin luas karena adanya rasa penasaran dan rasa ingin tahu yang tinggi sehingga bisa menyelesaikan masalah yang dihadapinya baik masalah yang terstruktur maupun tidak terstruktur. Sejalan dengan Ge \& Land (Yusepa, 2017) menyatakan bahwa masalah yang tidak terstruktur akan membuat siswa mengaitkan pengetahuan matematika abstrak dengan kehidupan sehari-hari hingga mereka mampu untuk berpikir abstrak. Berpikir abstrak, menyusun masalah, dan menggeneralisasi dalam kehidupan sehari-hari adalah proses abstraksi matematis.

Sebagai seorang pendidik, guru berperan penting dalam meningkatkan motivasi siswa untuk belajar agar siswa mendapatkan hasil belajar yang optimal dan berprestasi, salah satunya bisa diterapkan melalui media pembelajaran. Dengan menggunakan media pembelajaran bisa menggiring siswa untuk mencapai kemampuan abstraksi, dimana pada media pembelajaran ini tertuang konsep matematik mulai dari konkrit sampai pada pembuatan model matematik, disanalah pola pikir abstraksi siswa akan terbentuk. Menurut (Widyawati \& Prodjosantoso, 2015) media pembelajaran yang diterapkan oleh guru sangat mempengaruhi minat dan motivasi siswa untuk belajar. Pembelajaran matematika tidak lepas dari media dan bahan ajar yang digunakan. Implementasi bahan ajar yang dilakukan pada siswa pada materi bangun datar segiempat kesulitan siswa dapat teratasi (Prayogi, Praja, \& Raharjo, 2019). Bahan ajar yang digunakan oleh siswa tidak terlihat adanya kesulitan siswa dalam mengerjakan bahan ajar, melainkan siswa aktif dalam belajar
(Syutaridho, Zulkardi, \& Hartono, 2012). Peningkatan kemampuan berpikir kreatif matematik siswa SMP dengan menggunakan bahan ajar lebih baik daripada yang menggunakan pembelajaran biasa (Sari \& Nurjaman, 2019).

Namun, sesuai dengan hasil wawancara pada salah satu siswa di lapangan bahwa; 1) media dan bahan ajar yang digunakan pada proses belajar masih terkesan kurang menarik sehingga membuat siswa menjadi bosan dan kurang termotivasi untuk belajar terutama belajar materi segiempat dan segitiga, 2) kurangnya penggunaan media pembelajaran, dan 3) bahan ajar yang digunakan dominan dengan kalimat yang monoton tanpa adanya gambar/animasi yang unik yang bisa mengunggah semangat belajar siswa.

Dengan demikian, diperlukan bahan ajar dan media pembelajaran yang memiliki kualitas baik untuk menarik motivasi siswa belajar. Dimana kedua hal tersebut memiliki arti yang berbeda, menurut (Herawati, 2015) bahan ajar adalah materi yang dirancang dan disusun secara sistematis, digunakan untuk membantu guru dalam melaksanakan kegiatan belajar mengajar. Sedangkan menurut (Wibowo, 2016) media pembelajaran adalah alat, teknik atau bahan yang digunakan dalam kegiatan belajar mengajar dengan tujuan agar proses interaksi pada edukasi antara guru dengan siswa maupun siswa dengan siswa dapat berlangsung secara tepat guna dan berdayaguna.

Untuk mengatasi masalah tersebut, solusi yang inovatif dan kreatif salah satunya ialah dengan membuat bahan ajar berbantuan tubomatika. Pengembangan bahan ajar berbantuan media tubomatika ini bisa digunakan sebagai media interaktif dari berbagai 
kesulitan siswa yang dihadapinya dalam materi segiempat dan segitiga, karena penyusunan bahan ajar disesuaikan dengan kebutuhan pada materi pembelajaran.

Bahan ajar tubomatika adalah suatu bentuk sajian materi segitiga dan segiempat dengan seri desain gambar menggunakan gambar tubomatika. Tubomatika merupakan suatu media pembelajaran matematika yang bisa digunakan sebagai alat fisik untuk menyampaikan isi materi pengajaran melalui berbagai bentuk/variasi dari media Tubomatika. Tubomatika ini terbuat dari tutup botol plastik bekas yang di daur ulang kembali menjadi suatu karya buatan, dapat dibentuk dan dirangkai sesuai dengan kebutuhan pada materi yang ditentukan. Dengan tampilan tubomatika, dapat menghantarkan logika siswa dari objek nyata (konkrit) menjadi objek bayangan (abstrak) sehingga siswa dapat memahami konsep segitiga dan segiempat yang saling berkaitan satu sama lain, baik mencari konsep keliling, luas maupun unsur yang terdapat pada segiempat dan segitiga. Pada bahan ajar ini disajikan pula lembar kerja siswa (LKS) yang harus dikerjakan oleh siswa sebagai bentuk latihan setelah belajar dan terdapat beberapa soal segitiga dan segiempat sebagai bentuk tantangan bagi siswa untuk memecahkan masalah matematika secara kompleks.

Dengan adanya pengembangan bahan ajar berbantuan tubomatika yang valid, praktis dan efektif ini diharapkan siswa dapat memahami materi matematika dengan lebih baik. Oleh sebab itu, penelitian ini memiliki tujuan untuk melihat proses dan hasil pengembangan bahan ajar berbantuan tubomatika berdasarkan hasil analisis lembar observasi keterlaksanaan pembelajaran, angket respon guru dan siswa terhadap proses pembelajaran, dan efektif terhadap peningkatan kemampuan abstraksi matematis siswa SMP yang diperoleh dari hasil tes akhir siswa.

\section{METODE PENELITIAN}

Metode pada penelitian ini adalah penelitian pengembangan melalui penggunaan model pengembangan Plomp. Pada pengembangan bahan ajar materi segiempat dan segitiga berbantuan tubomatik ini menggunakan model pengembangan yang diadaptasi dari model Plomp. Model ini dikembangkan oleh Plomp, terdiri dari 3 tahap antara lain; 1) fase investigasi awal dengan melakukan analisis kurikulum, analisis siswa dan analisis konsep, 2) fase pengembangan (pembuatan prototipe) dengan melakukan rancangan bahan ajar berbasis tubomatika, dan 3) fase penilaian yang diujicobakan di SMPN 23 Bandung, Jawa Barat. Populasi pada penelitian ini adalah seluruh siswa SMP di Kota Bandung, sampelnya dipilih secara purposive sampling ialah satu kelas pada satu sekolah di kawasan kota Bandung, Jawa Barat. Sampel penelitian adalah siswa kelas VII SMPN 23 Bandung, jumlah siswa 33 orang dimana 18 orang perempuan dan 15 orang laki-laki, karena sesuai dengan studi pendahuluan kemampuan siswanya heterogen, sehingga mudah untuk diberikan inovasi-inovasi baru dalam pembelajaran. Penelitian dilakukan selama 1 bulan pada bulan Februari 2020 dengan 8 kali pertemuan.

Instrumen pengumpulan data yang digunakan adalah daftar wawancara, lembar observasi, angket dan tes akhir. Daftar wawancara digunakan pada proses pendahuluan terhadap guru dan kurikulum, lembar observasi digunakan untuk melihat pelaksanaan 
pembelajaran dengan menerapkan bahan ajar berbasis tubomatika, angket diberikan dan diisi langsung oleh siswa dan untuk melihat kepraktisan bahan ajar yang dikembangkan, sedangkan tes akhir dilakukan untuk melihat pengembangan penggunaan bahan ajar berbantuan tubomatika terhadap kemampuan abstraksi siswa dalam proses pembelajaran.

Teknik pengumpulan data pada penelitian ini adalah tes soal untuk mendapatkan hasil pekerjaan siswa dalam menyelesaikan soal kemampuan abstraksi matematis pada materi segitiga dan segiempat, wawancara, dan angket terbuka. Hasil tes dianalisis yang didasarkan pada indikator kemampuan abstraksi matematis, antara lain; 1) pengintegrasian dan perumusan masalah, 2) transformasi masalah ke dalam simbol matematika, 3) membuat generalisasi, 4) pembentukan konsep matematika terkait konsep yang lain, dan 5) pembentukan objek matematika yang lebih lanjut.

Teknik pengolahan data untuk bahan ajar berbantuan tubomatika menggunakan analisis validitas produk, pengolahan data pelaksanaan pembelajaran melalui angket guru dan siswa menggunakan analisis praktikalitas, dan pengolahan data tes akhir siswa menggunakan analisis keefektifan.

\section{Teknik Analisis Validitas Produk}

Produk yang menjadi penilaian pada analisis validasi ialah perangkat pembelajaran terdiri dari rencana pelaksanaan pembelajaran (RPP) dan bahan ajar berbasis tubomatika. Penilaian dilakukan berdasarkan angket yang telah diisi oleh 2 orang guru matematika di SMPN 23 Bandung, kemudian dianalisis untuk mengetahui tingkat kevalidan dari produk yang dikembangkan. Analisis validitas menggunakan Skala Likert dengan langkah-langkah:

a. Memberikan skor untuk setiap item jawaban positif sangat setuju (4), setuju (3), tidak setuju (2), dan sangat tidak setuju (1). Begitupun dengan sebaliknya, jika untuk setiap item jawaban negatif maka sangat setuju (1), setuju (2), tidak setuju (3), dan sangat tidak setuju (4).

b. Menjumlahkan skor total tiap validator untuk seluruh indikator.

c. Pemberian nilai validitas dengan menggunakan rumus (1):

$$
\mathrm{V}=\frac{f}{N} \times 100 \%
$$

dimana $\mathrm{V}$ : nilai akhir, $\mathrm{f}$ : perolehan skor dan N: skor maksimum. Hasil atau nilai yang diperoleh dari uji validitas kemudian diinterpretasikan sesuai dengan kategori pada Tabel 1.

Tabel 1. Kategori validitas.

\begin{tabular}{cc}
\hline Interval & Kategori \\
\hline $81 \%-100 \%$ & Sangat Valid \\
$61 \%-80 \%$ & Valid \\
$41 \%-60 \%$ & Cukup Valid \\
$21 \%-40 \%$ & Tidak Valid \\
$0-20 \%$ & Sangat Tidak Valid \\
\hline Dimodifikasi dari (Riduwan, 2010) \\
\end{tabular}

Suatu produk bahan ajar berbasis tubomatika dikatakan praktis apabila siswa dapat memahami isi materi pada bahan ajar tersebut dan bisa mengkonstruksikan media tubomatika dengan baik. Analisis data angket praktikalitas bahan ajar berbasis tubomatika berdasarkan angket siswa dengan langkah-langkah berikut:

a. Memberikan skor untuk setiap item jawaban sangat setuju (4), setuju (3), tidak setuju (2), dan sangat tidak setuju (1). 
b. Menjumlahkan skor total untuk seluruh indikator.

c. Pemberian nilai praktikalitas dengan menggunakan rumus (2):

$$
\mathrm{P}=\frac{f}{N} \times 100 \%
$$

Dengan P: Nilai akhir, f: Perolehan skor, dan N: Skor maksimum. Hasil atau nilai yang diperoleh dari uji praktikalitas kemudian diinterpretasikan sesuai dengan kategori pada Tabel 2.

Tabel 2. Kategori praktikalitas.

\begin{tabular}{cc}
\hline Interval & Kategori \\
\hline $81 \%-100 \%$ & Sangat Praktis \\
$61 \%-80 \%$ & Praktis \\
$41 \%-60 \%$ & Cukup Praktis \\
$21 \%-40 \%$ & Tidak Praktis \\
$0-20 \%$ & Sangat Tidak Praktis \\
\hline
\end{tabular}

Dimodifikasi dari (Riduwan, 2010)

\section{Teknik Analisis Efektivitas}

Analisis efektifitas pada data hasil tes akhir siswa dilakukan dengan langkah-langkah sebagai berikut:

d. Memberikan skor untuk setiap butir soal, jika jawaban benar ada unsur yang diketahui, ditanya, penyelesaian dan kesimpulan (5), jawaban benar, ada unsur yang diketahui, ditanya dan penyelesaian (4), jawaban benar, unsur diketahui dan ditanya salah (3), jawaban benar tetapi tidak ada unsur diketahui dan ditanya (2), jawaban ada tetapi salah (1), dan tidak ada jawaban (0).

e. Menjumlahkan skor total untuk seluruh butir soal.

f. Pemberian nilai efektifitas dengan menggunakan rumus (3)

$$
\mathrm{E}=\frac{f}{N} \times 100 \%
$$

dimana E: Nilai akhir, f: Perolehan skor, dan N: Skor maksimum.
Tabel 3. Kategori efektifitas.

\begin{tabular}{cc}
\hline Interval & Kategori \\
\hline $81 \%-100 \%$ & Sangat Efektif \\
$61 \%-80 \%$ & Efektif \\
$41 \%-60 \%$ & Cukup Efektif \\
$21 \%-40 \%$ & Tidak Efektif \\
$0-20 \%$ & Sangat Tidak Efektif \\
\hline Dimodifikasi dari (Riduwan, 2010) \\
Hasil dari uji efektivitas kemudian \\
diinterpretasikan sesuai dengan kategori \\
pada Tabel 3.
\end{tabular}

\section{HASIL DAN PEMBAHASAN}

Langkah pertama yang dilakukan pada penelitian ini ialah pada fase pengembangan investigasi awal dengan melakukan analisis yang terdiri dari; 1) analisis kurikulum, 2) analisis siswa, dan 3) analisis konsep. Pada analisis kurikulum melalui empat komponen yaitu tujuan, isi, metode dan evaluasi dengan menyesuaikan Kompetensi Inti dan Kompetensi Dasar pada materi segitiga dan segiempat kelas VII SMP. Analisis siswa pada pengembangan ini dilakukan untuk mengetahui karakteristik siswa agar sesuai dengan konsep dan desain pengembangan perangkat pembelajaran dan pelaksanaan pembelajaran dapat berlangsung dengan baik. Sesuai dengan hasil wawancara yang dilakukan terhadap salah satu guru di SMPN 23 Bandung, Ibu Nurhayati mengatakan bahwa kemampuan abstraksi sangat diperlukan bagi siswa terutama siswa sekolah menengah pertama, namun pada konteks abstraksi siswa masih dikatakan belum memiliki pemikiran yang kompleks terhadap pembelajaran, sesuai dengan ajaran yang berlandaskan pada kurikulum 2013 bahwa pembelajaran akan lebih efektif dan bermakna apabila dalam proses pembelajarannya diterapkan bahan ajar 
yang sesuai dengan materi sehingga dengan penggunaan bahan ajar tersebut dapat meningkatkan motivasi dan prestasi siswa dalam belajar. Sesuai Sejalan dengan (F Nurhasanah, Kusumah, \& Sabandar, 2017) "the mathematical abstraction to be learnt so that all those ntions cannot be just transferred into students' mind like a bunch of information that should be memorized" yang berarti bahwa abstraksi matematika tidak dapat ditransfer begitu saja dalam bentuk informasi, melainkan harus dikonstruksi dalam benak mereka sendiri. Sedangkan pada analisis konsep ini dilakukan dengan mengidentifikasi konsep pokok yang akan diajarkan yaitu pada materi segitiga dan segiempat, merinci konsepkonsep individu ke dalam hal yang kritis dan yang tidak relevan. Analisis konsep yang telah dilakukan adalah mengidentifikasi bagian-bagian penting dan utama yang akan dipelajari kemudian menyusun submateri yang relevan secara sistematis yang akan masuk pada bahan ajar berdasarkan prasyarat, petunjuk penggunaan, Standar Kompetensi (SK), Kompetensi Dasar (KD), Kriteria Keberhasilan dan Peta Konsep yaitu bahan ajar berbasis tubomatika.

Selanjutnya fase pengembangan atau pembuatan prototipe diawali dengan merancang bahan ajar matematika berbasis tubomatika meliputi RPP dan bahan ajar. Hasil rancangan perangkat pembelajaran kemudian dilakukan evaluasi dan direvisi berdasarkan hasil yang ada. Selanjutnya dilakukan validasi, dikatakan valid apabila perangkat yang dirancang memenuhi kriteria valid. Hasil uji validitas pada perangkat pembelajaran dapat dilihat pada Tabel 4.
Tabel 4. Hasil uji validitas bahan ajar berbasis Tubomatika.

\begin{tabular}{clc}
\hline No & $\begin{array}{l}\text { Perangkat } \\
\text { Pembelajaran }\end{array}$ & $\begin{array}{c}\text { Validitas } \\
(\boldsymbol{\%})\end{array}$ \\
\hline 1 & $\begin{array}{l}\text { Rencana } \\
\text { Pelaksanaan }\end{array}$ & $82 \%$ \\
& $\begin{array}{l}\text { Pembelajaran } \\
2\end{array}$ & Bahan Ajar \\
\hline
\end{tabular}
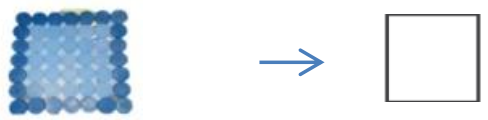

Persegi
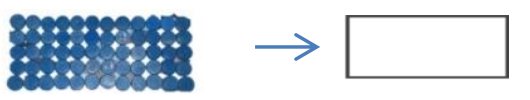

Persegi

Panjang
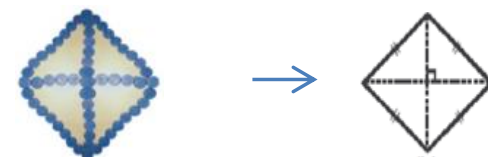

Belah

Ketupat
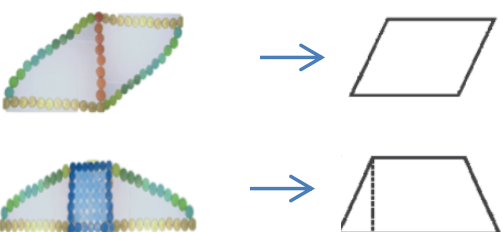

Jajar Genjang
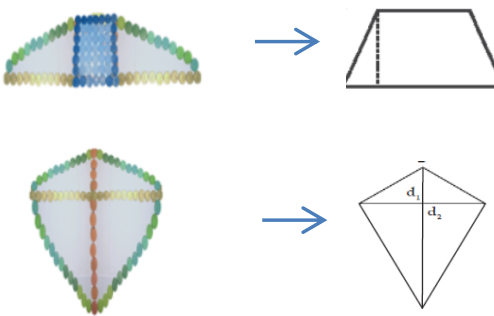

Layanglayang

Gambar 1. Desain tubomatika bentuk segiempat.

Pada validasi RPP, nilai validitas mencapai $82 \%$ artinya kategori validitas RPP adalah sangat valid, hal ini menunjukkan bahwa sebagian besar RPP dapat dikatakan bagus bagi pelaksanaan skenario pembelajaran. Selanjutnya tingkat validasi bahan ajar mencapai $87 \%$ dengan kriteria sangat bagus dan bahan ajar ini relevan untuk digunakan dalam pembelajaran. Kedua perangkat pembelajaran tersebut sudah 
DOI: https://doi.org/10.24127/ajpm.v9i3.2918

dikatakan valid karena sesuai dengan indikator penilaian validitas yang terdiri dari empat komponen, yaitu komponen kelayakan isi, komponen kebahasaan, komponen sajian, dan komponen kegrafisan. Sajian dari desain tubomatika dapat dilihat pada Gambar 1 dan Gambar 2.

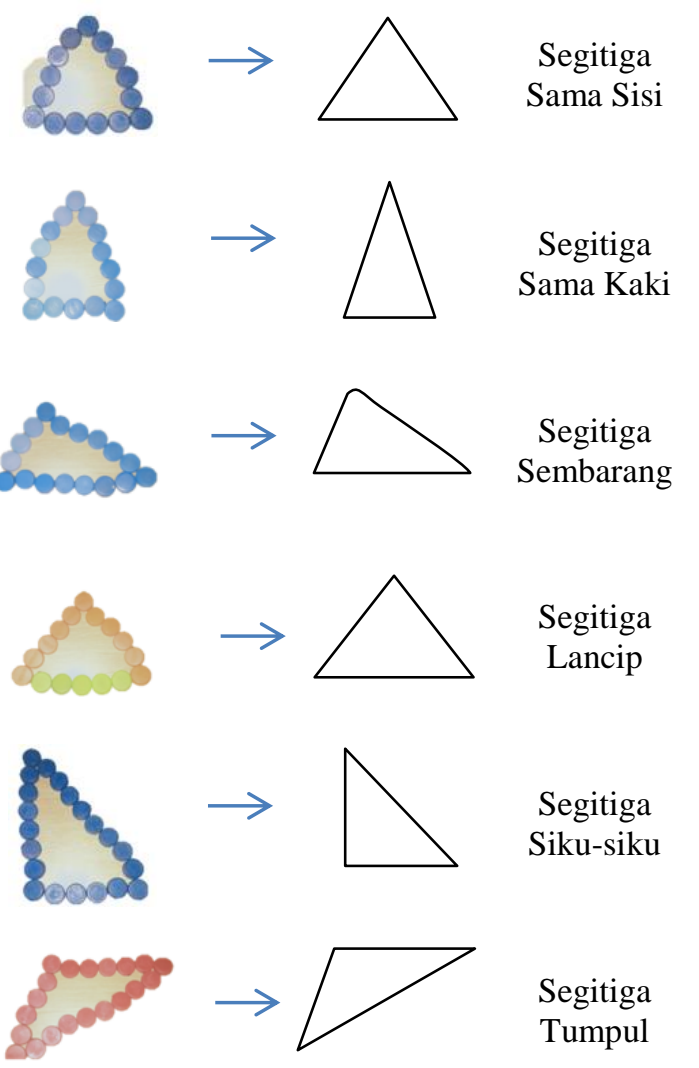

Gambar 2. Desain tubomatika bentuk segitiga.

Berdasarkan Gambar 1 dan Gambar 2, dapat dilihat bahwa bentuk segiempat dan segitiga dirangkai dengan memanfaatkan tutup botol. Dengan melalui desain tubomatika, menghantarkan siswa berpikir objektif dalam mensketsa kembali pada bentuk geometri secara abstrak hingga memahami jenis-jenis segitiga, jenisjenis segiempat, apa itu sisi, sudut, keliling dan luas. It is can be seen from activities such us measuring the length of the sides of triangle using ruler, folding paper, rotating the image of the shape to saw a figure of shape from many point of view, and trying to draw a segment in a figure to help the student understanding the concept (Nurhasanah, 2011). Bahkan siswa akan menemukan sendiri mengenai definisi segiempat dan segitiga melalui konsep tubomatika. Segiempat dan segitiga termasuk konsep geometri yang terdapat pada teori matematika, "The triangle and rectangle is part of geometry concept. They are subject have an important role in help students to solve problems encounter in daily life. This can be done by modeling the problem into a mathematical model" artinya segitiga dan segiempat adalah bagian dari konsep geometri, serta memiliki peranan penting dalam bantuan siswa untuk memecahkan masalah yang dihadapi dalam kehidupan sehari-hari. Ini dapat dilakukan dengan memodelkan masalah menjadi model matematika (Ningsih, Nurlaelah, \& Jupri, 2018).

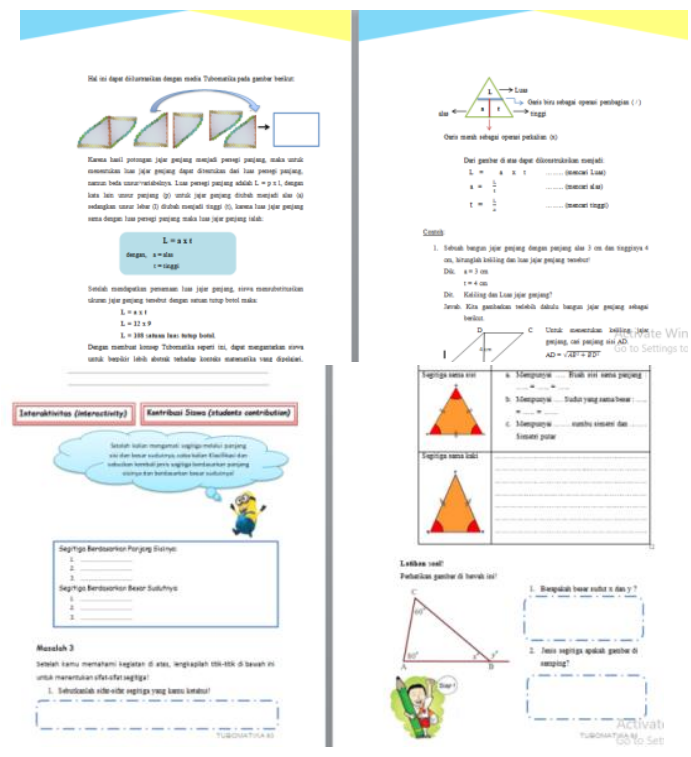

Gambar 3. Desain isi bahan ajar berbasis tubomatika. 
DOI: https://doi.org/10.24127/ajpm.v9i3.2918

Selain dari desain media tubomatika, adapula contoh isi LKS dari bahan ajar. Isi bahan ajar berbasis tubomatika dikemas dengan berbagai desain yang unik, seperti adanya gambar animasi, kalimat motivasi, bahkan konsep matematik yang bisa membuat siswa paham terhadap materi yang diajarkan. Contoh dari desain isi dapat dilihat pada Gambar 3.

Hasil wawancara pada siswa:

$\mathrm{P}$ : Selamat siang, dek.

S2 : siang bu.

$\mathrm{P}$ : nama kamu siapa dek?

S2 : Albi, bu.

$\mathrm{P}$ : oiya, Albi coba ibu mau tanya nih. Tadi Albi sudah belajar apa?

S2 : iya bu, tadi aku belajar segiempat sama segitiga pakai bahan ajar tubomatika.

$\mathrm{P}$ : tubomatika itu apa ya?

S2 : tubomatika itu media yang menjelaskan materi segiempat dan segitiga bu.

P : coba kamu jelaskan bagaimana cara menghitung keliling dan luas salah satu segiempat menggunakan tubomatika?

S2 : misal mencari keliling persegi kita tinggal hitung tutup botol pada tubomatika yang bagian sisinya bu, terus dijumlahkan karena sisinya ada 4 jadi

$\mathrm{s}+\mathrm{s}+\mathrm{s}+\mathrm{s}=7+7+7+7=28$ tutup botol. Kalau luas persegi panjang kita menggunakan satuan tutup botol, jadi tinggal hitung saja semua tutup botol yang membentuk persegi panjang itu bu atau $\mathrm{L}=\mathrm{p} x$ $1=12 \times 5=60$ satuan tutup botol. (contoh ada pada Gambar 4)

P : wah, hebat Albi pintar sekali. Albi senang tidak belajar menggunakan bahan ajar tubomatika itu?

S2 : aku seneng banget bu, di bahan ajar itu ada gambarnya, terus ada kotak isian yang harus diisi juga jadi itu tantangan buat aku buat belajar, dan bisa belajar langsung pakai media tubomatika dari tutup botol itu.

$\mathrm{P}$ : oke, Albi semoga kamu jadi anak yang pintar dan berprestasi yaaa terus semangat belajarnya.

S2 : iya bu, makasih.
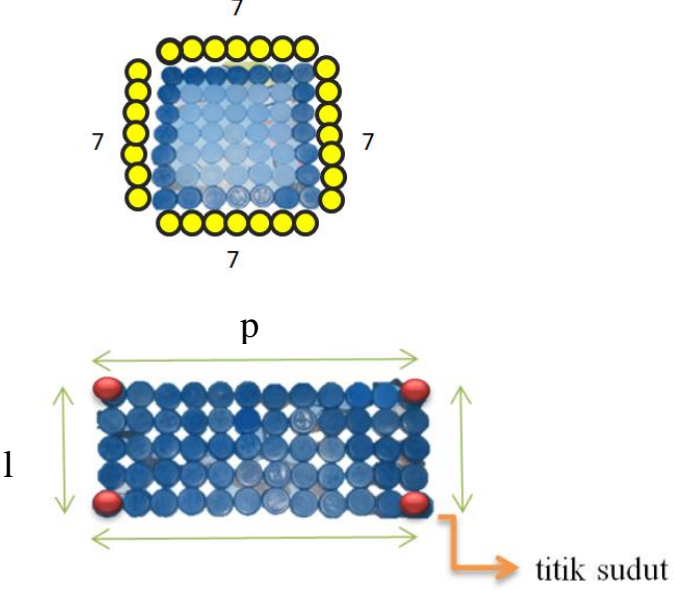

Gambar 4. Desain tubomatika untuk persegi dan persegi panjang.

Pada hasil wawancara di atas terlihat bahwa siswa memberikan respon positif terhadap pembelajaran dengan menggunakan bahan ajar berbasis tubomatika, sehingga siswa bisa langsung mengkonstruksi dan menjelaskan konsep segiempat dan segitiga dengan baik melalui Gambar 4 . Dengan demikian penggunaan bahan ajar ini perlu dikembangkan lebih lanjut untuk proses pembelajaran matematika terutama pada materi segiempat dan segitiga di jenjang berikutnya.

Selanjutnya fase praktikalitas, dilakukan oleh guru dan siswa. Data uji praktikalitas terhadap bahan ajar berbasis tubomatika oleh guru diperoleh melalui angket. Evaluasi dilakukan setelah pembelajaran matematika materi segiempat dan segitiga selesai di setiap 
pertemuan. Uji praktikalitas ini bertujuan untuk melihat kepraktisan dari bahan ajar berbasis tubomatika yang digunakan, berdasarkan hasil respon guru yaitu bahan ajar tersebut sangat layak untuk diterapkan pada pembelajaran materi segiempat dan segitiga pada Adapun rincian hasil uji praktikalitas terhadap bahan ajar berbasis tubomatika oleh guru disajikan pada Tabel 5.

Tabel 5. Rata-rata hasil uji praktikalitas oleh guru.

\begin{tabular}{ccc}
\hline Pertemuan & $\begin{array}{c}\text { Angket } \\
\text { Guru }\end{array}$ & Kategori \\
\hline 1 & $71,42 \%$ & Praktis \\
2 & $75 \%$ & Praktis \\
3 & $82,14 \%$ & Sangat Praktis \\
4 & $85,71 \%$ & Sangat Praktis \\
5 & $85,71 \%$ & Sangat Praktis \\
6 & $85,71 \%$ & Sangat Praktis \\
7 & $89,28 \%$ & Sangat Praktis \\
8 & $91,07 \%$ & Sangat Praktis \\
Rata-rata & $83,25 \%$ & Sangat Praktis \\
\hline
\end{tabular}

Dari Tabel 5 diperoleh nilai ratarata hasil uji praktikalitas guru mencapai lebih dari $60 \%$, sehingga diperoleh $83,25 \%$ dengan kategori sangat praktis. Hal ini menunjukkan bahwa perangkat pembelajaran bahan ajar berbantuan tubomatika yang dikembangkan begitu praktis untuk digunakan oleh siswa dalam pembelajaran materi segiempat dan segitiga.

Selain itu, adapun uji praktikalitas oleh siswa dapat dilihat pada Tabel 6. Berdasarkan Tabel 6 terlihat bahwa nilai rata-rata praktikalitas oleh siswa mencapai 81,16 dengan kategori sangat praktis. Selanjutnya, Berdasarkan hasil analisis praktikalitas pada Tabel 5 dan Tabel 6 dapat dinyatakan bahwa adanya tanggapan-tanggapan positif terhadap perangkat pembelajaran yang digunakan serta telah sesuai dengan indikator praktikalitas yang terdiri dari empat komponen yaitu komponen kemudahan penggunaan, komponen manfaat, komponen kemenarikan, dan komponen kejelasan bahan ajar.

Tabel 6. Rata-rata hasil uji praktikalitas oleh siswa.

\begin{tabular}{ccc}
\hline Pertemuan & $\begin{array}{c}\text { Angket } \\
\text { Siswa }\end{array}$ & Kategori \\
\hline 1 & $80,05 \%$ & Sangat Praktis \\
2 & $78,48 \%$ & Praktis \\
3 & $82,95 \%$ & Sangat Praktis \\
4 & $82,95 \%$ & Sangat Praktis \\
5 & $73,63 \%$ & Praktis \\
6 & $80,51 \%$ & Sangat Praktis \\
7 & $80,68 \%$ & Sangat Praktis \\
8 & $90,05 \%$ & Sangat Praktis \\
Rata-rata & $81,16 \%$ & Sangat Praktis \\
\hline
\end{tabular}

Setelah uji validitas dan praktikalitas, selanjutnya dilakukan uji efektivitas terhadap bahan ajar berbantuan tubomatika, uji ini dilakukan untuk melihat sudah sejauh mana keefektifan bahan ajar terhadap peningkatan kemampuan abstraksi matematis siswa kelas VII SMP. Efektifitas bahan ajar dilihat berdasarkan hasil tes akhir yang soalsoalnya disusun berdasarkan indikator kemampuan abstraksi matematis. Hal ini menunjukkan bahwa penggunaan bahan ajar berbantuan tubomatika untuk materi segiempat dan segitiga termasuk kategori baik (efektif). Uji efektifitas dikatakan efektif jika siswa dapat menjawab 5 soal tes yang disusun berdasarkan indikator abstraksi matematis. Berikut ini efektifitas bahan ajar berbasis tubomatika terhadap kemampuan abstraksi matematis siswa, dapat disajika pada Tabel 7. 
DOI: https://doi.org/10.24127/ajpm.v9i3.2918

Berdasarkan Tabel 7, nilai terendah yang diperoleh siswa pada tes adalah 58,79\% pada indikator pengintegrasian perumusan masalah, hal ini berarti bahwa kemampuan siswa dalam merumuskan masalah masih belum maksimal misalnya apa yang diketahui dari suatu masalah dan apa yang ditanyakan, dan nilai tertinggi yang didapatkan adalah $82,42 \%$ pada indikator transformasi masalah ke dalam bentuk simbol, hal ini berarti siswa sudah mampu menggunakan model matematika yang dirancang dari suatu masalah, serta diketahui bahwa nilai rata-rata sebesar $71,27 \%$ dengan kategori efektif. Hal ini menunjukkan bahwa bahan ajar berbantuan tubomatika efektif untuk digunakan dalam proses peningkatan kemampuan abstraksi matematis siwa kelas VII SMP.

Tabel 7. Hasil uji efektifitas bahan ajar berbasis tubomatika.

\begin{tabular}{clcc}
\hline $\begin{array}{c}\text { No } \\
\text { Soal }\end{array}$ & \multicolumn{1}{c}{ Indikator } & $\%$ & Kategori \\
& & & \\
\hline 1 & pengintegrasian dan perumusan masalah & $58,79 \%$ & Cukup efektif \\
2 & transformasi masalah ke dalam bentuk simbol, & $82,42 \%$ & Sangat efektif \\
3 & membuat generalisasi & $70,30 \%$ & Efektif \\
4 & pembentukan konsep matematika terkait konsep yang & $69,70 \%$ & Efektif \\
& lain & & \\
5 & pembentukan objek matematika & $75,15 \%$ & Sangat efektif \\
& Rata-rata & $71,27 \%$ & Efektif \\
\hline
\end{tabular}

Adapun faktor yang mempengaruhi pengembangan bahan ajar berbantuan tubomatika, antara lain; 1) kecermatan isi bahan ajar, 2) penyajian materi pada bahan ajar, 3) pengemasan bahan ajar yang menarik, 4) keutuhan konsep, dan 5) penggunaan bahasa. Sehingga dengan menggunakan bahan ajar berbantuan media tubomatika tersebut akan berdampak baik bagi perkembangan pola pikir sisi, dimana siswa dapat lebih memahami konsep segiempat dan segitiga yang saling berkaitan, siswa lebih termotivasi untuk belajar karena pada penyajiannya disertakan ilustrasi/ gambar yang menarik, dengan begitu akan meningkatkan pengetahuan siswa dan prestasi belajar siswa meningkat bahkan siswa bisa berpikir lebih kreatif (Sari \& Nurjaman, 2019).

\section{KESIMPULAN DAN SARAN}

Berdasarkan pengembangan bahan ajar berbantuan media tubomatika diperoleh hasil validasi bahan ajar tersebut sangat valid. Selanjutnya dari hasil uji coba kepraktisan produk yang dilakukan dapat dikatakan bahwa kepraktisan bahan ajar berbantuan tubomatika tersebut tergolong kriteria baik. Sedangkan pada tahap pengembangan efektivitas bahan ajar sangat baik dalam penggunaan bahan ajar terhadap peningkatan kemampuan abstraksi matematis siswa SMP. Dengan kata lain, bahan ajar berbantuan tubomatika ini sangat efektif untuk digunakan dalam pembelajaran pada materi segiempat dan segitiga.

Berdasarkan hasil penelitian, maka saran yang dapat diberikan oleh peneliti yaitu; 1) bahan ajar berbantuan tubomatika agar dapat digunakan dalam 
DOI: https://doi.org/10.24127/ajpm.v9i3.2918

proses pembelajaran pada materi segiempat dan segitiga, 2) sebagai pendidik guru harus terbiasa menggunakan bahan ajar berbantuan tubomatika agar guru mampu menguasai materi, sehingga pembelajaran tidak akan terkesan moton dan membosankan, bahkan akan membangkitkan semangat siswa dalam belajar, 3) perlu adanya pengembangan lebih lanjut terhadap bahan ajar berbantuan tubomatika untuk melengkapi kekurangan pada bahan ajar tersebut, dan 4) penggunaan bahan ajar berbantuan tubomatika ini dapat disebarluaskan sehingga akan lebih manfaat bagi pembaca khususnya para pelajar matematika. Semoga penelitian berikutnya dapat lebih baik dan media tubomatika bisa lebih diperbanyak lagi untuk kelangsungan pembelajaran matematika terutama pada materi segiempat dan segitiga.

\section{DAFTAR PUSTAKA}

Basri, H. (2019). Investigating Critical Thinking Skill of Junior High School in Solving Mathematical Problem. International Journal of Instruction, 12(3), 745-758.

Herawati, L. (2015). Pengembangan Bahan Ajar Matematika Menggunakan Aplikasi Imind Map di SMP Negeri 3 Sumber. IAIN Syekh Nurjati Cirebon.

Mandasari, N. (2018). Analisis Proses Abstraksi Matematika dalam Memahami Konsep dan Prinsip Geometri Ditinjau dari Teori Van Hiele. Jurnal Pendidikan Matematika: Judika Education, 1(2), 61-70.

Ningsih, D. R., Nurlaelah, E., \& Jupri, A. (2018). Preliminary study on mathematical problem solving ability of junior high school students on the triangle subject. International Conference on Mathematics and Science Education of Universitas Pendidikan Indonesia, 3, 745-750.

Nurhasanah, F, Kusumah, Y. S., \& Sabandar, J. (2017). Concept of triangle: Examples of mathematical abstraction in two different contexts. International Journal on Emerging Mathematics Education, 1(1), 53-70.

Nurhasanah, Farida. (2011). Junior High School, Students" Abstraction in Learning (Geometry). Proceeding of International Seminar and the Fourth National Conference on Mathematics Education, 21-23.

Prayogi, A. H., Praja, E. S., \& Raharjo, J. F. (2019). Desain Bahan Ajar Bangun Datar Segiempat Berbasis Kemampuan Komunikasi Matematis pada Siswa SMP melalui Model Discovery Learning. LEMMA, 5(2), 100-111.

Riduwan. (2010). Belajar Mudah Penelitian dan Pengembangan. Bandung: Alfabeta.

Sari, I. P., \& Nurjaman, A. (2019). Pengembangan Local Instruction Theory pada Materi Segitiga dan Segiempat Terhadap Kemampuan Representasi Matematik Siswa SMP. Jurnal Pembelajaran Matematika Inovatif, 2(2), 95-100.

Sugandi, A. I. (2013). Pengaruh Pembelajaran Berbasis Masalah dengan Setting Kooperatif Jigsaw terhadap Kemandirian Belajar 
DOI: https://doi.org/10.24127/ajpm.v9i3.2918

Siswa SMA. Infinity Journal, 2(2), 144.https://doi.org/10.22460/infinit y.v2i2.31.

Yutaridho, Zulkardi, \& Hartono, Y. (2012). Pengembangan Bahan Ajar Keliling, Luas Persegi dan Persegi Panjang dengan Pendekatan Pendidikan Matematika Realistik Indonesia. Jurnal Pendidikan Matematika, 6(1), 1-18.

Wibowo, N. (2016). Upaya peningkatan keaktifan siswa melalui pembelajaran berdasarkan gaya belajar di SMK Negeri 1 Saptosari. Elinvo (Electronics, Informatics, and Vocational Education), 1(2), 128-139.
Widyawati, A., \& Prodjosantoso, A. K. (2015). Pengembangan media komik IPA untuk meningkatkan motivasi belajar dan karakter peserta didik SMP. Jurnal Inovasi Pendidikan IPA, 1(1), 24-35.

Yusepa, B. (2017). Kemampuan abstraksi matematis siswa Sekolah Menengah Pertama (SMP) KLS VIII. Symmetry: Pasundan Journal of Research in Mathematics Learning and Education, 1(1), 5460. 